\title{
Essay
}

\section{College Students' Views of Work-Life Balance in STEM Research Careers: Addressing Negative Preconceptions}

\author{
Anna Tan-Wilson and Nancy Stamp \\ Department of Biological Sciences, Binghamton University-SUNY, Binghamton, NY 13902-6000 \\ Submitted November 20, 2014; Revised April 22, 2015; Accepted April 22, 2015 \\ Monitoring Editor: Alison Gammie
}

\begin{abstract}
In career discussions, female undergraduates said that if they were to attend graduate school in science, technology, engineering, and mathematics (STEM) and were to follow a career based on their research training, they would have to give up having a family. A subsequent survey showed that many students, both men and women, thought work-life balance would be more difficult to achieve in a STEM research path than in other professions they were considering. Their views of STEM research being less family-friendly were more pronounced on issues of parental leaves and caring for children than finding a spouse/partner and landing two jobs in the same locality. To provide role models of work-life balance in STEM professions, we convened panels of dual-career couples who described how they worked together to raise their children while advancing their scientific careers. Our selection of panelists and topics of discussion were based on findings of social science research on work-life balance. On a survey with the same questions administered afterward, the changes in paired responses of male and female students with respect to all four issues showed a significant shift toward thinking that a research-based STEM career would be no more difficult than other careers they were considering.
\end{abstract}

\section{INTRODUCTION}

Given today's reliance on science and technology in almost all sectors of the world economy and the need to solve serious global problems, the low percentage (24\%) of U.S. college graduates who earned degrees in science, technology, engineering, and mathematics (STEM), 27th in the developed world, is alarming (National Academy of Sciences, National Academy of Engineering, Institute of Medicine, 2010). To illustrate the deficit, in 2011, when the level of U.S. unemployment was relatively high, with 3.6 unemployed people for every job posting, there were twice as many job postings for STEM skills as there were unemployed people

CBE Life Sci Educ September 2, 2015 14:es5

DOI:10.1187/cbe.14-11-0210

Address correspondence to: Anna Tan-Wilson (annatan@binghamton .edu).

(C) 2015 A. Tan-Wilson and N. Stamp. CBE-Life Sciences Education (C) 2015 The American Society for Cell Biology. This article is distributed by The American Society for Cell Biology under license from the author(s). It is available to the public under an Attribution-Noncommercial-Share Alike 3.0 Unported Creative Commons License (http:/ / creativecommons.org/licenses/by-nc-sa/3.0).

"ASCB ${ }^{\circledR}$ " and "The American Society for Cell Biology ${ }^{\circledR}$ " are registered trademarks of The American Society for Cell Biology.
(Change the Equation, 2011). Exacerbating the problem is the fact, documented just recently, that only $26 \%$ of college students who graduate with STEM degrees are employed in STEM occupations (Landivar, 2013b; U.S. Census Bureau, 2014). Assuming the trend continues, based on the count of students earning bachelor's degrees in science and engineering in 2012 (National Center for Education Statistics, 2013), that means $\sim 200,000$ STEM college graduates per year will not end up in STEM occupations (using the U.S. Census Bureau's definition of STEM degrees and occupations). Understanding and addressing reasons why students who succeeded in obtaining a STEM degree move on to occupations outside the field will help mitigate the current and worsening shortage of STEM workers in the United States.

For the past four years, our institution has conducted a program with STEM undergraduates doing interdisciplinary research on problems relating to the life sciences. Because these students performed exceptionally well in their academic and research work, we hoped they would choose to attend graduate school in STEM and, from that base of advanced research training, proceed to diverse careers in academia, government, or industry. Their graduate-level research training could lead them into scientific/engineering research in academia, government, or industry; or their training could be applied toward 
commercialization of research, bioethics, public policy, or science writing (Fuhrmann et al., 2011; D'Ecclessis, 2013; Turk-Bicakci et al., 2014; Columbia University Center for Career Education, 2015). Thus, knowing that part of the solution to the STEM shortage is to increase diversity among students in STEM fields (Landivar, 2013a; National Girls Collaborative Project, 2013), we listened very carefully when, in discussions about career choices, the women pursuing majors in engineering, computer science, and the physical sciences voiced serious concern about being able to manage family along with a career in a STEM profession.

\section{Multiple Aspects of Work-Life Balance}

The students' concerns that they would not be able to raise a family while also developing a career based on graduate training in STEM fields are addressed in social science research as one aspect of work-life balance. Besides their roles at work, individuals are also sons and daughters, siblings, friends, members of social organizations, and eventually spouses/partners and then parents, with the relative importance of these work and nonwork roles changing and varying in importance through the life stages (Demerouti et al., 2012). For instance, the importance of social life and hobbies may give way to family responsibilities as a person commits to a life partner and the couple has children. Research recognizes that work and personal life domains can impact one another in positive and negative ways (Carlson et al., 2000, 2006; Grawitch et al., 2010). For instance, individuals experience conflict when aspects of work such as stressful relationships with managers or coworkers or long unpredictable work hours make it difficult to manage family time; or when caring for family reduces efficiency at work. Enrichment results when fulfillment at work (e.g., self-esteem, financial security) and transfer of skills, behaviors, and perspectives at work help a person be a better family member; or when the need to attend to family provides workers with focus and sense of urgency that result in greater efficiency at work. Work-life balance is thus defined as feeling effective and satisfied in both work and personal life domains (Greenhaus and Allen, 2011). Individuals try to minimize or manage conflicts between work and nonwork, and to maximize the benefits that spill over from work to nonwork and vice versa (Kalliath and Brough, 2008). As individuals' roles in the work force and in the family change with time, different aspects of work-life balance take priority.

\section{Work-Life Balance Gender Differences}

Research shows that, today, work-life balance is an issue for both men and women (Parker and Wang, 2013); however, studies show that conflicts and rewards associated with dual roles of men and women at work and in the family are different (Rothbard, 2001). Work-to-family enrichment, spillover of positive experiences at work that lead to a richer family life, was found to be significant for men but not for women. Family-to-work enrichment, when a fulfilling experience as a family member spills over to work, was significant for women but not for men. Women are more likely than men to adjust their work-modifying work schedules, taking parttime work, choosing less demanding work, shifting careers, or turning down opportunities for career advancementto accommodate family commitments (Adema, 2013).
These differences are ascribed to men and women having internalized divergent societal expectations, that men have primary responsibility for work and women have primary responsibility for the family (Rothbard, 2001), resulting in women still carrying the larger share of housework and child care even when they have full-time employment (Miranda, 2011; Parker and Wang, 2013). Gender differences regarding balancing work and family were already apparent in college students even though the students were not married, had no children, and did not have full-time employment. In that study, 39\% of the women, compared with only $7 \%$ of the men, estimated below-median work commitment along with above-median family commitment (Friedman and Weissbrod, 2005). Men and women also differed in their timing with regard to their thoughts about marriage and parenting; men were more likely than women to have not yet given thought to these issues, and women more likely than men to have already made decisions as to whether they would marry and have children.

\section{Importance of Work-Life Balance to the Millennial Generation}

Traditional college students today belong to the Millennial generation. Millennials, compared with Boomers and Gen- $X$, tend to place more value on jobs that "leave a lot of time for other things in life" (Twenge et al., 2010). That study was based on surveys of STEM workers taken when they were still attending high school and showed that Millennials' desire for better work-life balance starts long before they consider having children. In part of a worldwide survey of Millennials (National Chamber Foundation, 2012), it was evident that members of this group were willing to work hard but also wanted work-life balance. For residents from Canada and the United States, the top answer to the question "If you could prioritize your life, what would you emphasize?" was "To spend time with my family," with 56-60\% making this choice compared with $35 \%$ choosing "To have a successful career." "To be able to have time to enjoy my hobbies" and "To have many good friends" were selected by $<25 \%$ of the North American respondents, showing the greater importance of balancing work with family rather than with personal interests.

\section{Relevance of Work-Life Balance Issues to STEM}

A partial solution to the deficit of STEM workers is for employers to help workers balance work and family. In a study of men and women who graduated from a large public university from 1965 to $1990,32 \%$ of the women and $16 \%$ of the men left science after starting science careers, with the women outnumbering the men two to one (Preston, 2004). Inability to combine family with a scientific career was one of the top reasons given by the women, who either stopped working outside the home or shifted to nonscience occupations. Indeed, in a study of physics and chemistry doctoral graduate students, postdoctoral fellows, and scientists in academia and industry, women (39\%) were twice as likely as men $(20 \%)$ to have made choices that compromised their careers in order to meet family needs (Wyss and Tai, 2010). Early in their careers, the challenge was that of finding employment for both partners in the same geographical area, made more difficult by the location of many institutions that employ research scientists in small cities and rural areas. 
The next challenge was usually associated with the birth of children, reflected in women who had children more likely to leave scientific occupations compared with women who had no children, whereas men who had children were more likely to stay compared with men who had no children. Data from studies undertaken to determine the loss of women from careers in academic science show that women $(29 \%$ of graduate students and $12 \%$ of postdoctoral associates) more than men (7\% for both groups) worry that a science career will keep them from having a family (Goulden et al., 2009; Mason et al., 2009). Another study established that the perceived as well as actual inability to have the desired number of children was the major contributor to career dissatisfaction among male and female scientists (Ecklund and Lincoln, 2011). These apprehensions are especially acute for Ph.D. scientists in academic careers, because the delay in childbearing to pursue graduate studies results in the pre-tenure years, when faculty members must amass an impressive body of research, coinciding with women's peak fertility years (Williams and Ceci, 2012).

\section{Importance of Self-Efficacy with Respect to Future Work-Life Balance on Career Choices}

Family role models are major influences on young people's attitudes toward work (Loughlin and Barling, 2001). College students who grew up in a family in which both parents shared housework and child care had lower anticipation of work-family conflicts and stronger self-effiicacy, that is, belief they could manage both work and family, compared with students who had grown up in traditional households in which their mothers did most of the housework and caring for children (Cinamon, 2006). Because work-life balance is in part dependent on the type of work a person does, a young person's perception of future work-life balance may have some influence on the person's career decisions. Self-efficacy, defined as a person's beliefs concerning his/her ability to perform a task or behavior successfully, influences career choices by determining the types of career exploration that the person will attempt and results in higher levels of persistence when faced with obstacles (Betz, 2004). Inasmuch as a person anticipates lack of future work-life balance as an obstacle to a desired career, having a concept of oneself forging a career while enjoying family life contributes to self-efficacy with respect to work-life balance; and self-efficacy with regard to work-life balance has been shown to actually result in lower levels of conflict between work and nonwork (Fouad et al., 2012). Such self-concept can be developed by exposure to positive role models (Gibson, 2003).

\section{METHODS}

Knowing of our female undergraduates' concerns that research-based careers in STEM following graduate study would not be compatible with raising families and understanding that work-life balance is also an issue for men, we worried that many of our students who were being groomed for careers requiring graduate research training in STEM would opt for other professions that they perceived to be more family-friendly, a common strategy for reducing future work-family conflicts (Chait Barnett et al., 2003). We realized that, to encourage our students to choose graduate studies in
STEM upon graduation, we needed to assuage their anxieties about work-life balance in STEM professions. On the basis of research on how young adults make career decisions, we designed an intervention to provide our students with positive role models of STEM professionals who balance work and family and thus to help them make choices based on reliable information. We also conducted surveys before and after the panel events to determine the efficacy of the intervention. This was done each year, resulting in a total of four cohorts of students.

\section{Intervention: Work-Family Panel Discussions}

To provide the role models, we invited two to three dual-career couples, each with a female STEM professional who we knew shared household and child-care responsibilities with her partner. We wanted the students to consider that they did not have to work and raise a family by themselves. We wanted them to realize that the ability to balance work and family depended on both partners (Glass et al., 2013). This was also in line with a UK Parliament report that stressed the importance of choosing dual-career couples instead of women alone as role models, so as not to convey the idea that only a "superwoman" can have both a scientific career and a family (Science and Technology Committee, 2014). We invited couples with young children, because we wanted the role models to be as close in age to the students as possible, and these couples could address current practices for parental leaves, access to day care for infants, and other assistance now provided by employers not available in past decades. The couples on our panels happened to be either both STEM faculty members or a STEM faculty member married to a healthcare practitioner. Although some couples served on the panels in multiple years, the set of couples changed from year to year.

When issuing the invitation, we briefly described the kinds of questions or topics to address; and during the panel session, we occasionally prompted the panelists with questions. On the basis of our understanding that students were more concerned about their future roles as spouses and parents than having leisure time for hobbies and friends, we asked our panelists to focus on how they balanced work and family, to recount how they met, and how they landed two jobs in the same location. We knew that their talking about their experiences would show students how institutions' hiring practices help dual-career couples. We asked panelists to follow with a discussion of parental leaves and of how they manage sharing of child-care responsibilities. Except for the physical setup, with panelists sitting in the front of the room facing the group of 25-30 students, we kept the event informal, providing an atmosphere in which the panelists could be relaxed and the undergraduates could be comfortable with asking questions. The panelists' stories described the milestones in their family lives and careers and how they managed work and family through each transition. Their real-life narratives illustrated workplace and family characteristics that improve work-life balance: the advantage of having control of work schedules (Tausig and Fenwick, 2001), the value of flexibility both in the workplace (Council of Economic Advisers, 2010) and in the home. Partners who were both in academia talked about how scheduling their classes at different times gave them the flexibility to deal 


\begin{tabular}{|c|c|c|c|c|c|c|c|}
\hline \multicolumn{8}{|l|}{ WORK-LIFE BALANCE SURVEY } \\
\hline \multicolumn{8}{|c|}{$\begin{array}{l}\text { If you think work-life balance will be the same for persons who follow research-based STEM careers in academia, } \\
\text { government or industry compared to other professions; e.g. health professions, management, finance, on each of the issues, } \\
\text { select SAME. Select } 1 \text { for a little easier or a little harder. Select } 2 \text { for easier or harder. Select } 3 \text { for much easier or much } \\
\text { harder }\end{array}$} \\
\hline $\begin{array}{l}\text { Write down one or two examples of another profession (not research-based STEM } \\
\text { career) that you specifically have in mind as you answer this. If nothing specific, leave } \\
\text { this box blank, then proceed to the other questions with a generic non-research STEM- } \\
\text { based profession in mind. }\end{array}$ & \multicolumn{3}{|c|}{$\begin{array}{l}\text { Easier with } \\
\text { research- } \\
\text { based STEM } \\
\text { career than } \\
\text { other } \\
\text { professions } \\
\end{array}$} & \multirow[t]{2}{*}{$\begin{array}{l}\text { S } \\
A \\
M \\
E\end{array}$} & \multicolumn{3}{|c|}{$\begin{array}{r}\text { Harder with } \\
\text { research- } \\
\text { based STEM } \\
\text { career than } \\
\text { other } \\
\text { professions } \\
\end{array}$} \\
\hline Issues & 3 & 2 & 1 & & 1 & 2 & \\
\hline \multicolumn{8}{|l|}{$\begin{array}{l}\text { (1) Will I still be able to meet my future spouse / partner? } \\
\text { If you have a spouse, fiancé, significant other, partner, leave this blank }\end{array}$} \\
\hline \multicolumn{8}{|l|}{ (2) Will my spouse / partner be able to find jobs in the same geographical location? } \\
\hline \multicolumn{8}{|l|}{$\begin{array}{l}\text { (3) Will my career be set back as I take time to have a child / children } \\
\text { (maternity/paternity leave)? }\end{array}$} \\
\hline (4) As I work at my career, will I have time to spend with my child / children? & & & & & & & \\
\hline
\end{tabular}

Figure 1. Format for responses in work-life balance survey comparing a career based on STEM research with an alternative career.

with emergencies relating to children. They spoke about taking turns assuming more responsibility in the home when the other had a critical deadline to meet at work. The situations, circumstances, and experiences the panelists shared with the students provided rich examples of how scientists and engineers manage their family lives while also advancing their careers.

\section{Undergraduate STEM Students in the Study}

The research students who attended the panel discussions were undergraduates in the STEM disciplines on our campus. Of the 127 students in our program, $45 \%$ were majors in the life sciences, while $55 \%$ were majors in the physical sciences, mathematics, computer science, and engineering. Both sets of majors were about evenly divided between juniors and seniors. Forty-six percent of the students were underrepresented by gender or ethnicity in their disciplines. At the time of the panel discussions, the students had completed nine weeks of full-time summer research with stipend support, followed by five months of research for independent study credit during the Fall and Spring semesters. A total of 52 men and 50 women, comprising $80 \%$ of the program participants, attended the panel discussions and filled out surveys before (prepanel) and after (postpanel) the panel discussion. Each year there was a new cohort of students; thus there were four cohorts with 11, 9, 20, and 12 men and 8, 15, 14, and 13 women, respectively. All students were of traditional college age with birth years from 1990 to 1994, placing them in the Millennial generation. None was married and none had children. We also asked the students about their career goals, specifically whether they were planning to proceed to graduate school, whether they intended to remain in STEM, and how important the issue of balancing future work and family was to them.

\section{Surveys on Work-Family Issues}

In the prepanel survey, we gave students four specific issues of work-life balance to consider. The issues reflected the types of concerns voiced informally by students in the first cohort and were presented in the form of questions: (Q1) meeting their future spouses/partners, (Q2) finding two jobs in the same location, (Q3) the impact on their careers of taking parental leave, and (Q4) having time to spend with children (Figure 1). Thus, Q1 and Q2 focused on issues relating to their future spouses/partners and Q3 and Q4 focused on issues relating to children.

With graduation from college in a few months for some or a little more than a year away for others, important career decisions were imminent for the students. In addition to graduate studies in STEM, many were also considering graduate studies to prepare for professions in other areas such as healthcare, finance, and K-12 education. Except for the availability of positions in some of these professions having wider geographical distribution that would make it easier for both spouses/partners to advance their careers, we knew from the literature that those professions also posed challenges to work-life balance (Resneck, 2006; Cinamon et al., 2007; Elliott, 2011; Shelton, 2013). For instance, as medical students and residents seek work-life balance, there is intense competition for medical residencies in specialties in which work is conducted within set hours (Elliott, 2011). Even $\mathrm{K}-12$ teachers, who have jobs that are generally considered to be family-friendly, report typical 60-h workweeks during the school year and the need to work at another job in the summer to supplement income (Tucson Values Teachers, 2013). Thus, although in general, a career in STEM would be no easier or harder than the other professions they were considering, we surmised that the students' apprehensions originated from them having little to no contact with STEM professionals outside of the college campus and thus having only glimpses of STEM professionals' private lives. We formulated the anonymous survey in such a way that students would visualize themselves both working as STEM professionals after having completed an advanced degree with research training in a STEM discipline and in alternative professions. The students were instructed to indicate with checkmarks on a two-sided scale the relative ease 


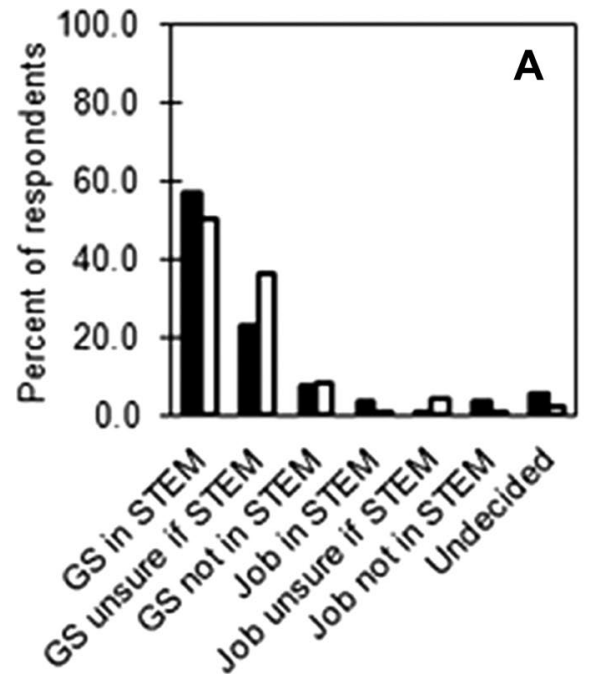

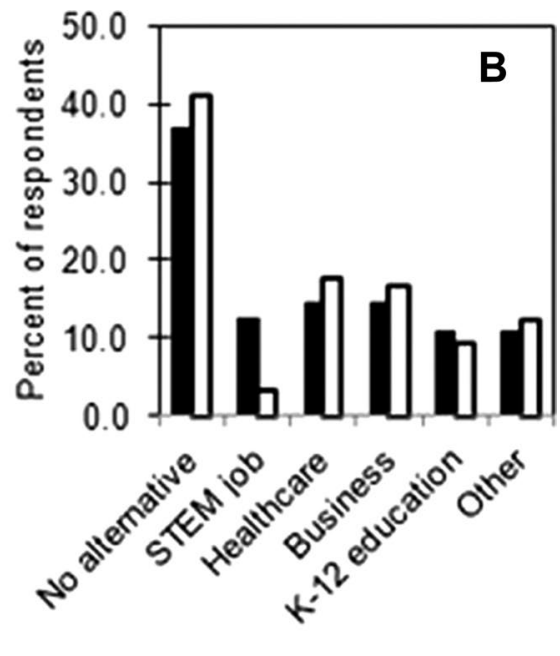

Figure 2. Students' career goals. (A) Postgraduate plans of the men and the women. GS, graduate studies. Contingency table analysis showed no significant difference between the two groups $\left(\chi^{2}(6, N=102)=\right.$ $3.24, p=0.52)$. (B) Alternative careers being considered by the men and the women. When two careers were given, half-point tallies were assigned to each. Contingency table analysis showed no significant difference between the two groups $\left(\chi^{2}(5, N\right.$ $=102)=0.330, p=0.99)$. $(\mathrm{A}$ and $\mathrm{B})$ men $(n=$ 52 , solid), women $(n=50$, clear). or difficulty of managing work and family in research-based STEM careers compared with the alternative (Figure 1). Those who were not considering a career other than in STEM were asked to think in generic terms of such an alternative. Administering the survey immediately before and after the panel discussions gave the students an opportunity to reflect on the panels' information in the context of their own lives. We kept track of individual students' pre- and postpanel responses so we could determine what effect, if any, the panel discussions had on the students' views.

\section{Scoring Surveys}

Responses on whether balancing family with career would be easier or harder in a research-based STEM profession compared with an alternative career were scored as follows: much easier $(-3)$, easier $(-2)$, a little easier $(-1)$, same $(0)$, a little harder $(+1)$, harder $(+2)$, much harder $(+3)$ with a STEM career.

\section{Data Analysis}

Given that social science research pointed to differences in how men and women viewed and coped with the challenge of balancing work and family, we analyzed the survey responses of the men and women separately. Because the students' responses in the surveys did not conform to a normal distribution, we used the Kruskal-Wallis one-way analysis of variance by ranks for nonparametric data to examine patterns among cohorts. Where there was no significant difference among cohorts, the data were combined for further analysis. To compare responses of the men and the women, we used the Mann-Whitney $U$-test. To determine whether the panel discussions had an effect, we analyzed pre- and postpanel responses of each individual using the Wilcoxon signed-rank test. In addition, contingency table analyses were performed to test for gender differences in postgraduation plans, alternative careers, and the importance of balancing work and family. An alpha level of 0.05 was used for all statistical tests. Free-form comments were categorized and tabulated.

\section{RESULTS}

\section{Students' Career Goals}

The postgraduation plans of the men and women were similar, with $87 \%$ of the men and $94 \%$ of the women planning to pursue graduate studies after receiving the bachelor's degree (Figure 2A). More than half of the students bound for graduate school were planning to continue in a STEM discipline, and a small number planned on shifting to non-STEM disciplines. Some students $(26 \%$ of the men and $38 \%$ of the women) were unsure whether their graduate studies would be in a STEM discipline. Only $4 \%$ of the men and $2 \%$ of the women were planning to work immediately after graduation.

In the prepanel survey, students were asked to name the alternative careers they were considering (Figure 2B). More than a third of the students (37\% of the men and $41 \%$ of the women) did not give an alternative to a research-based STEM career. Most of the other students gave two alternative careers in many different combinations. The list included STEM jobs that were attainable with a bachelor's degree, the health professions (medicine, dentistry, nursing), business (accounting, consulting, finance), K-12 education, and other careers related to food production (farming, brewing industry), law, law enforcement and social welfare, art (graphic design and music), and aviation. The responses of the men and the women were similar.

\section{Importance of Work-Life Balance to Students}

We asked the students to rate the importance of being able to balance work and family. The students overwhelmingly chose "very important" or "important" (Figure 3), with no significant difference between responses of the men and the women.

\section{Comparison across Cohorts}

Because we had different sets of panelists each year, we compared the responses given to each question by the students in each cohort, separated by gender (Supplemental Table 1). 


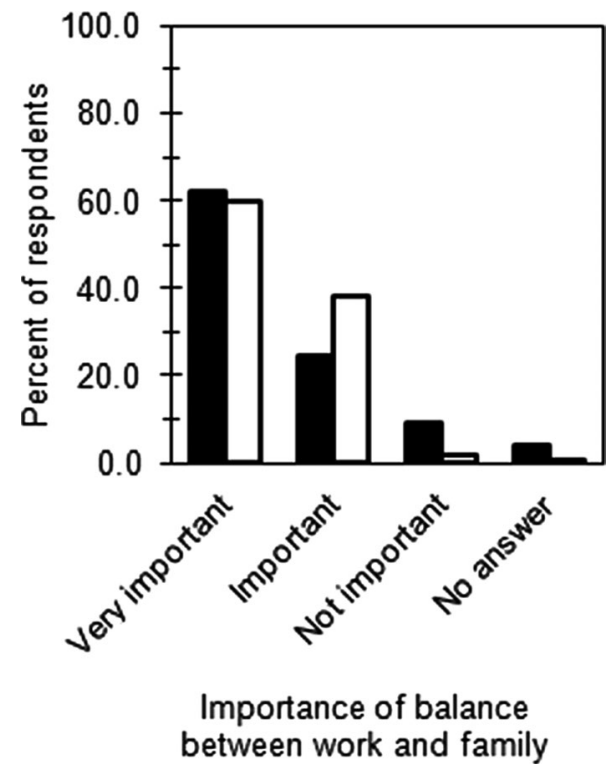

Figure 3. Opinions of the men and the women regarding the importance of work-life balance, specifically balance between work and family. Contingency table analysis showed no significant difference between the two groups $\left(\chi^{2}(3, N=102)=5.85, p=0.12\right)$. Men $(n=52$, solid); women ( $n=50$, clear).

Not finding any significant differences among them, we combined the responses of the four cohorts of men to each question and did likewise for the four cohorts of women.

\section{Before-Panel Survey Responses}

The prepanel survey responses to the questions (Figure 1) were examined to assess the ease or difficulty that students anticipated in balancing family with a career in a research-based STEM profession compared with alternative careers they had in mind. The responses of the men and the women given before the panel discussions did not conform to a normal distribution and thus are presented in box-andwhiskers plots to indicate the median and quartile ranks as well as the 5th and 95th percentiles (Figure 4). Means are indicated by the white lines, with the values listed in Table 1A.

Views of Students before the Panel Discussions. In before-panel responses, students thought balancing family with careers in research-based STEM would be more difficult. The men's responses leaned toward thinking of STEM as being less family-friendly than the alternative careers they were considering, and the response levels to all four questions were similar (Table 1B). Specifically, for three questions (Q1, Q2, and Q4, relating to meeting one's future spouse/ partner, landing two jobs for spouse and self in the same location, and having time to spend with children), the men's responses at the median and the 25 th percentile were "same in STEM" as in an alternative career; however, the means were between "same" and "a little harder," as the concerns of those who thought work-life balance would be more difficult in STEM outweighed the others. For the question relating to parental leave (Q3), the median was "a little harder in STEM."

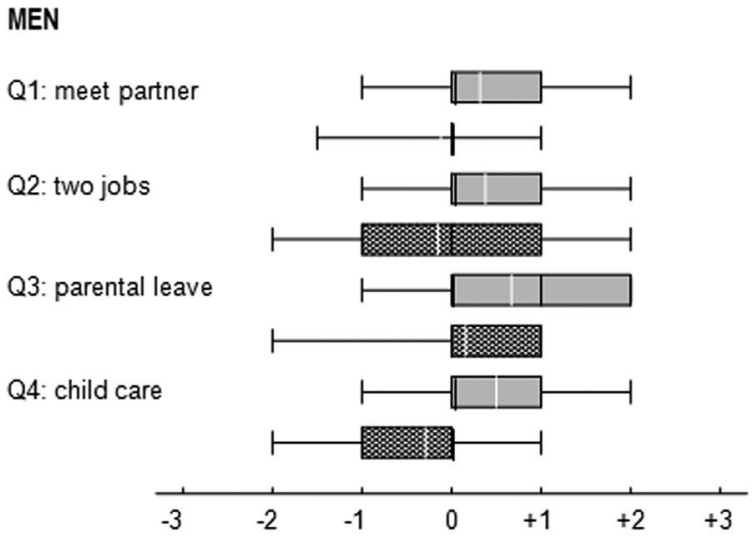

WOMEN

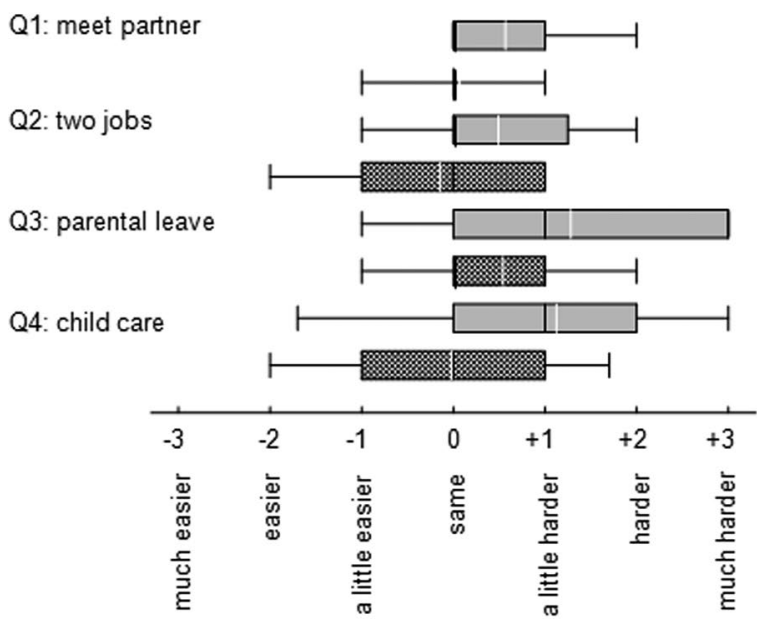

in research-based STEM

compared to alternative career

Figure 4. Box plots of the number-coded responses of the men and the women to questions on work-life balance surveys. The left-hand edge of the box represents the 25th percentile, the right-hand edge represents the 75th percentile, and the whiskers represent the 5th and 95th percentiles. The median is represented by a black line within the box. Thick box edges indicate situations in which the median coincides with the 25th and/or the 75th percentile. The white line within the box represents the mean. For each question, the top box plot (solid light gray) shows results of the prepanel survey, and the bottom box plot (hatched pattern) shows the results for the postpanel survey.

The analysis of the women's responses to the four questions showed that they also leaned toward thinking of STEM as being less family-friendly than the alternative careers they were considering, but there were significant differences in how the women thought of the four issues of work-life balance raised in the survey (Table 1B). As shown by the pairwise comparison of their responses to all the questions, there was no significant difference in how they rated research-based STEM in comparison with the alternative careers they were considering with respect to finding their future spouses/partners (Q1) and for them to find two jobs in the same geographical area (Q2). Similarly, there was no 
Table 1. Comparison of prepanel survey responses to different issues of work-family balance

\begin{tabular}{lcc}
\hline & & Mean of coded responses \\
\cline { 2 - 3 } A. Survey questions & Men & Women \\
\hline Q1 $\quad$ Will I still be able to meet my future spouse/partner? & +0.32 & +0.57 \\
Q2 $\quad$ Will my spouse/partner and I be able to find jobs in the same location? & +0.38 & +0.49 \\
Q3 $\quad$ Will my career be set back as I take time for maternity/paternity leave? & +0.67 & +1.28 \\
Q4 $\quad$ As I work at my career, will I have time to spend with my child/children & +0.50 \\
\hline
\end{tabular}

B. Responses to four questions compared

Men

Kruskal-Wallis $H$
$p$ value
Women
Kruskal-Wallis $H$
$p$ value

Survey questions compared Mann-Whitney $U$

$z$

$p$ value

0.749

2.401
0.493

14.645
$0.002^{* *}$

1 and Q2
1120.0
-0.32
0.749

C. Responses of men and women compared

Mann-Whitney $U$

$z$

$p$ value

Q1 and Q3
709.5
2.96
$0.003^{* *}$
Q1 and Q4
747.5
2.41
$0.016^{*}$
Q2 and Q3
807.5
2.92
$0.004^{* *}$
Q2 and Q4
1508.0
$-2.39$
$0.017^{*}$
Q3 and Q4
1133.5
0.47
0.634

\begin{tabular}{cccc} 
Q1 & Q2 & Q3 & Q4 \\
\hline 1224.0 & 1372.5 & 1629.0 & 1592.5 \\
-0.94 & -0.49 & -2.40 & -2.37 \\
0.347 & 0.624 & $0.016^{*}$ & $0.018^{*}$ \\
\hline
\end{tabular}

$*, p<0.05$.

$* *, p<0.01$.

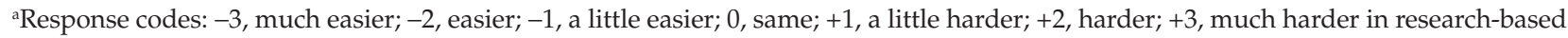
STEM compared with alternative career being considered.

significant difference in their responses to the issues relating to parental leaves (Q3) and having time to spend with their children (Q4). There was, however, a significant difference between how they viewed balancing work and family on the two issues relating to their spouses/partners (Q1 and Q2) compared with the two issues relating to children (Q3 and Q4), with the latter two identified as being more problematic in research-based STEM careers. Comparison of the box plots reflects this dichotomy (Figure 4). For Q1 and Q2, the responses at the median and the 25 th percentile were "same in STEM'; the means were between "same in STEM" and "a little harder in STEM." In contrast, for the questions that related to the impact of parental leave on their careers (Q3) and having time to spend with children (Q4), the responses at the median were "a little harder in STEM"; the means were slightly higher. The response at the 75th percentile for Q4 was "harder in STEM"; for Q3, it was "much harder in STEM."

Views of Men and Women Compared. We also compared how the men and the women responded to the questions before the panel discussions. There was no statistically significant difference in their responses to the two questions relating to their future spouses/partners (Q1 and Q2; Table 1C). For Q3 and Q4, the questions that addressed issues relating to future children, there were statistically significant differences in the responses of the men and the women, with the responses of the women showing greater anticipation of difficulty in research-based STEM professions compared with alternative careers they were considering.

\section{After-Panel Survey Responses}

We measured change in individual students' views by subtracting the number-coded prepanel response from the number-coded postpanel response for each survey respondent. The percentages of men and women who did or did not change their responses to each question are compared (Figure 5). To every question, at least $50 \%$ of the students gave responses different from those they had given before the panel discussion. The response that exhibited the highest percentage of change (83\%) was from the women, on the topic relating to spending time with children. Reviewing the change for each person across the four questions, we determined that only two men and one woman did not change their responses on all four topics. Thus, the panel discussions prompted $97 \%$ of the students to change their response on at least one challenge to balancing work and family.

Direction and Magnitude of Change. The direction and magnitude of the changes in response to each question are shown in Figure 6. It should be noted that, in this analysis, direction and magnitude of the change may be the same, while starting and end points may be different. For example, a change from "much harder in STEM" (+3) to "a little harder in STEM" (+1) and a change from "a little harder in STEM" $(+1)$ to "a little easier in STEM" (-1) would both be evaluated as change in the same direction (toward "easier in STEM") by the same magnitude (two intervals on the survey form). Changes in the direction toward "easier in STEM" are represented by stacked bars on the left; changes in the direction 


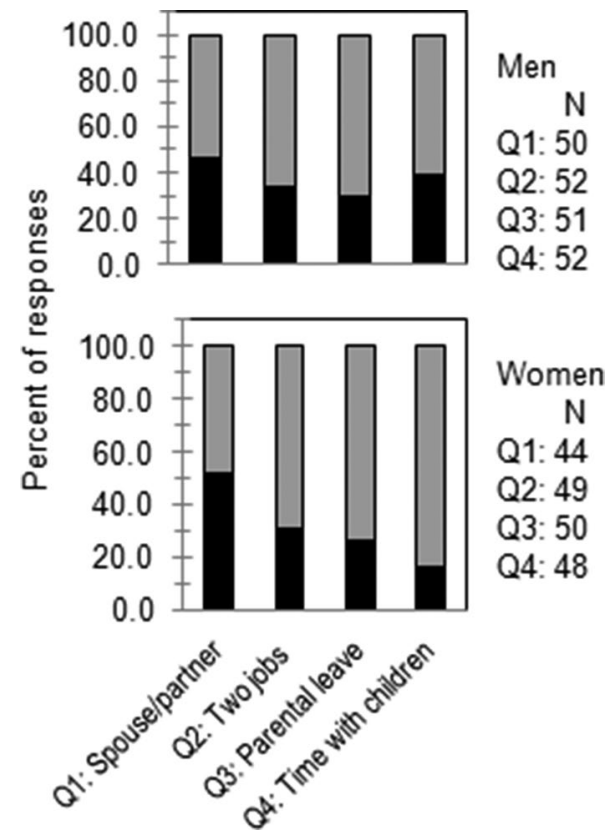

Figure 5. Percentage of work-life balance survey responses unchanged after the panel discussions. The percentages of responses that were not changed (black) and changed (gray) are represented in stacked bars. $N$, number of responses for each group. Top panel, men; bottom panel, women.

toward "harder in STEM" are represented by stacked bars on the right. The patterns of the stacked bars show the magnitude of change, with the solid section indicating the smallest change, corresponding to one interval on the survey form, progressing to two intervals (fine hatching), and three intervals (medium hatching). Few students shifted their answers by more than three intervals on the survey form, thus all changes from four to six intervals were combined and shown in the sections with the coarse-grained hatch marks. Plotted as described above, the longer lengths of bars on the left side compared with the bars on the right side indicate that higher percentages of men, and even more so for the women, made changes in the direction of "easier" rather than "harder" to balance family with careers in research-based STEM compared with an alternative career on all four issues. Inspection of the patterns on the stacked bars to the left also showed higher percentages of women registering changes of two or more intervals toward "easier in STEM."

The changes in the students' paired responses to all questions were statistically significant for both the men and the women (Table 2A). The results showed significant change for the men (Wilcoxon signed-rank test, $p<0.05$ for Q1, Q2, and $\mathrm{Q} 3 ; p<0.01$ for Q4), and for the women $(p<0.01$ for Q1, $\mathrm{Q} 2, \mathrm{Q} 3$, and Q4). The responses of the men and the women after the panel discussions clearly reflected a shift toward anticipation of less conflict and/or better balance between work and family than they initially thought possible in a research-based STEM career.

Views of Students after the Panel Discussions. We examined the postpanel survey data further to determine students' views as a result of the change in their thinking. We had hoped that, on the basis of the information conveyed by the panelists, the students would realize that a career built upon graduate research training in STEM would be compatible with having a family; that is, it would not be easier or more difficult than if they were in other professions that were also based on advanced degrees. Therefore, we compared the distribution of the students' after-panel responses (Figure 4, hatched box plots) to each question relative to the distribution of the responses before the panel (Figure 4, solid box plots). If we had achieved our goal, the median of the after-panel responses to all the questions would be at "same in STEM" as in an alternative career. The responses at the 25th percentile would be at either "same in STEM" or even "a little easier in STEM," while the responses at the 75th percentile would either be decreased to "a little harder in STEM" or even reach "same in STEM." This was indeed the result for all responses in the surveys administered after the panel discussions (hatched box plots). After the panel discussions, the responses at the median for both the men and the women were all at "same in STEM." Moreover, the after-panel responses for both the men and the women at the 25th percentile were at "same in STEM" as in an alternative career in answer to Q1 (finding partner) and Q3 (parental leave); and even at "a little easier in STEM" in answer to Q2 (two jobs) and Q4 (time with children). Furthermore, the after-panel responses for both the men and the women at the 75th percentile showed anticipation of better balance between work and family on the issues that raised the greatest concern previous to the panel discussions-Q3 (parental leave) for men and women and Q4 (time for children) for women. Where those responses were at "harder in STEM" or "much harder in STEM" before the panel discussions, third-quartile responses after the panel discussions were at "a little harder in STEM" and, in some cases, at "same in

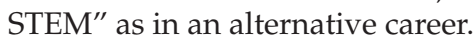

Views of Men and Women Compared. Before the panel discussions, compared with the men, the women anticipated that it would be more difficult to balance work and family in research-based STEM careers as opposed to the alternative careers they were also considering with respect to issues concerning parental leaves and having time to spend with children. In the postpanel responses, there was no statistically significant gender difference on any of the questions (Table 2B). This can be attributed to more women shifting in the direction of "easier" in research-based STEM and making shifts of larger magnitude to those questions. Thus, the overall outcome of the intervention was convergence of the large majority of students toward thinking of research-based STEM and alternative careers being the same with regard to ease or difficulty of achieving balance between work and family.

Views of a Minority. Nonetheless, the survey administered after the panel discussions showed a small number of students thinking it would be more difficult to balance work in a research-based STEM profession with raising a family (Figure 6, right panels). Although they were in the minority (five to 11 responses among the men and three to 10 responses among the women, depending upon the question, and only three men and one woman responded in this manner to all four questions), we were concerned, because these responses were in a direction opposite to what we had intended. Therefore, we examined the means of the individuals' before-panel responses and found that, in comparison with 
Table 2. Survey responses after panel discussions on work-life balance

\begin{tabular}{|c|c|c|c|c|}
\hline & Q1 Meet partner & Q2 Two jobs & Q3 Parental leave & Q4 Time with children \\
\hline \multicolumn{5}{|l|}{ Men } \\
\hline After-panel response mean & -0.12 & -0.15 & +0.16 & -0.29 \\
\hline Mean of change & -0.44 & -0.53 & -0.51 & -0.79 \\
\hline \multicolumn{5}{|l|}{ Change in paired responses } \\
\hline 75th percentile & 0 & 0 & 0 & 0 \\
\hline Number of respondents & 50 & 53 & 51 & 52 \\
\hline Number who changed & 27 & 35 & 35 & 32 \\
\hline$z$ & 2.26 & 2.39 & 2.26 & 3.29 \\
\hline$p$ value $^{\mathrm{b}}$ & $0.024^{*}$ & $0.017^{*}$ & $0.024^{*}$ & $0.001^{* *}$ \\
\hline \multicolumn{5}{|l|}{ Women } \\
\hline 25th percentile & -1 & -2 & -2 & -2 \\
\hline 50th percentile & 0 & 0 & -1 & -1 \\
\hline 75th percentile & 0 & 0 & 0 & 0 \\
\hline Number of respondents & 44 & 49 & 50 & 48 \\
\hline Number who changed & 21 & 34 & 37 & 40 \\
\hline$z$ & 2.58 & 2.83 & 2.95 & 4.14 \\
\hline$p$ value ${ }^{\mathrm{b}}$ & $0.001^{* *}$ & $0.005^{* *}$ & $0.003^{* *}$ & $<0.001^{* *}$ \\
\hline \multicolumn{5}{|c|}{ B. Responses of men and women compared } \\
\hline Mann-Whitney $U$ & 1181.5 & 1307.5 & 1397.5 & 1410.5 \\
\hline$z$ & -0.61 & -0.06 & -4.13 & -1.18 \\
\hline$p$ value $^{c}$ & 0.542 & 0.952 & 0.897 & 0.238 \\
\hline
\end{tabular}

${ }^{a}$ Change = after-panel response - before-panel response. Negative value: after panel discussions, shift was toward thinking of research-based STEM as more family-friendly compared with alternative careers being considered. Positive value: after panel discussions, shift was toward thinking of research-based STEM as less family-friendly compared with alternative careers being considered.

'By Wilcoxon signed-rank test, changes that are statistically significant are marked by asterisks. ${ }^{*}, p<0.05 ;{ }^{* *}, p<0.01$.

'By Mann-Whitney $U$-test, there was no statistically significant difference in the responses of the men and the women after the panel discussions.

the entire group in their gender, the minority group had initially viewed STEM as being more family-friendly relative to alternative careers (Figure 7). After the panel discussions, the responses of this minority group were more like those of the entire group before the panel discussions, even as the latter shifted to view STEM as being more family-friendly. Although this might seem to be a limitation of our intervention, we consider this result an indication that some students had not yet been confronted with these work-life balance issues, and the intervention was an early step in their relating to these issues.

\section{After-Panel Survey Comments}

At the end of the survey, students were invited to submit free-form comments. We received 45 comments from the men (85\% of the surveys) and 35 comments from the women $(70 \%)$. Comments that expressed the same sentiments were grouped (Table 3). Except for one student who was not receptive to the topic, all the other comments fell into two groups. Twenty of the comments described the information as good and insightful. They noted that the panel discus- sions gave perspective for their future decisions and that the discussions brought to light an aspect of life that most advisors do not address when giving career advice. The information was clearly enabling for the largest group, corresponding to $74 \%$ of the comments. There was obvious relief among the students in this latter group that it was possible to have a family while pursuing a career in STEM. Several wrote of their realization that it was possible to have a family with a STEM career. Some were pleased to find out that it would be easier than they thought it would be. Others made the observation that it would be hard but wrote about the guidance they received to make balancing work and family easier. Their comments showed that they had learned the importance of planning and of assistance from employers and the advantages of having a cooperative partner and of flexibility in the workplace. As we hoped, the panel discussions helped to build self-efficacy. Students expressed increased self-confidence in being able to balance work and family in the future. A common comment was that if they wanted both a research-based STEM career and a family, they could "make it work." 
Toward "Easier in STEM"

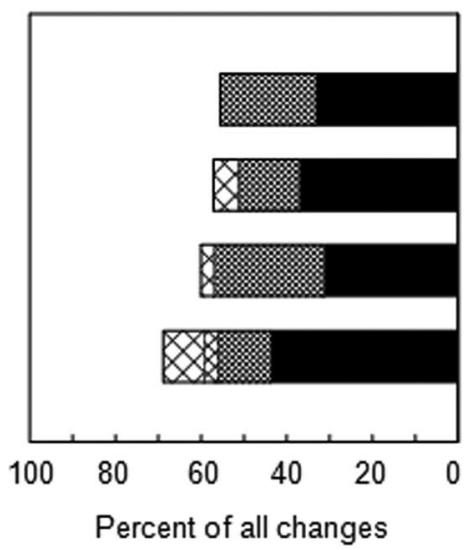

Toward "Easier in STEM"

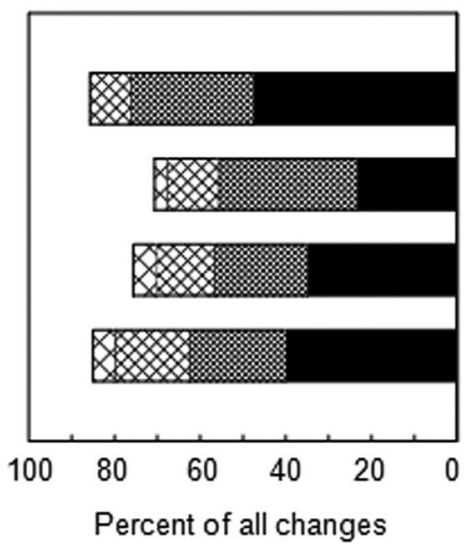

MEN

Meet future spouse/partner

Two jobs in same location

Parental leave career impact

Spending time with children

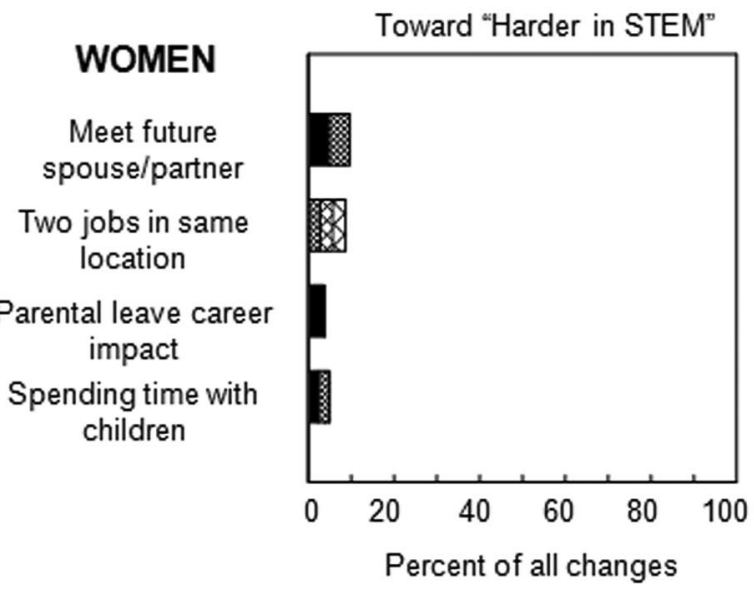

Figure 6. Direction and magnitude of the changes made by the men and the women after the panel discussions in response to the work-life balance survey. The $x$-axes represent the percentage of respondents who changed their responses, summing up to $100 \%$ for each question. Responses that shifted in the direction of "easier in STEM" are plotted on the left; responses that shifted in the direction of "harder in STEM" are plotted on the right. Patterns on stacked bars represent the magnitude of the change: black represents 1 interval on the survey form; the density of the hatched patterns represent other intervals: fine hatch, 2 intervals; medium, 3 intervals; coarse, 4-6 intervals.

\section{DISCUSSION}

Deficit in the STEM workforce is a problem that has attracted the attention of governments, leaders of industry, and educators (Committee on Science Engineering and Public Policy, 2010; National Center for Education Statistics, 2011; National Science Board, 2014). There are many barriers to surmount, starting with getting schoolchildren interested in science and ensuring that undergraduate science and engineering majors succeed in attaining their college degrees in STEM (Chen and Soldner, 2013; Graham et al., 2013). Our intervention addresses issues for students who surmounted those early barriers. At the time of their participation, they were successful STEM majors in college, with ongoing experience in STEM research. Most of these students were planning on further studies beyond the bachelor's degree, but many of them were undecided on whether to continue in a STEM discipline or to apply their STEM knowledge and skills in other areas, such as healthcare or business. Our in- tervention addressed the view among many of them that it would be especially difficult to balance work and family if their work were to be in research-based STEM careers, in jobs that require advanced research training in graduate school. Whereas their undergraduate research experiences encouraged them to think seriously about proceeding to graduate studies in STEM, they were also considering what else they wanted in their lives upon graduation. Our college students belong to the Millennial generation, a generation characterized as being more concerned with work-life balance than previous generations (Twenge et al., 2010). Considering that theirs is the largest living cohort size and forecast to be the most educated (Fry, 2015), thereby representing the most important source of the scientists and engineers of the next decades, we believe it is important for college faculty members and advisors to be aware that students' association of research-based STEM careers with poor work-life balance can be a barrier to college STEM graduates choosing to continue in STEM. 

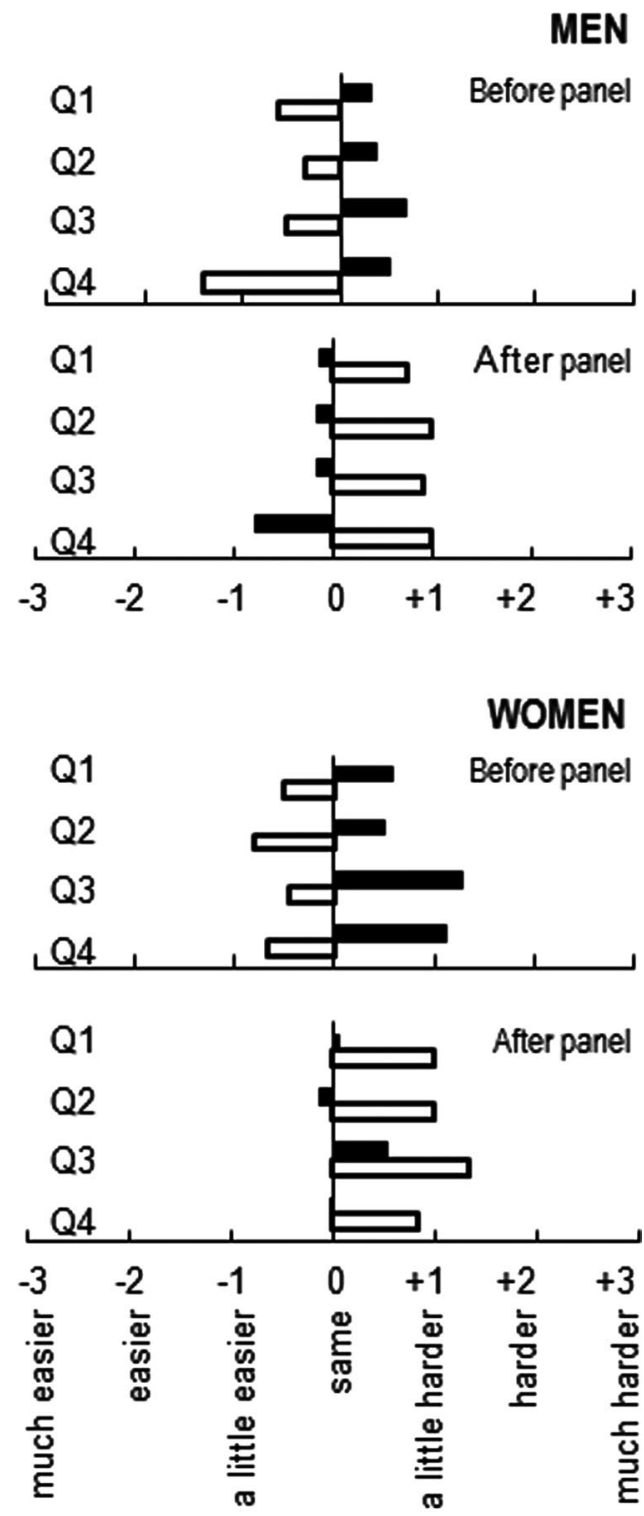

\section{in research-based STEM compared to alternative career}

Figure 7. Responses that changed to work-life balance being more difficult in research-based STEM relative to alternative careers. Bar graphs show the means of before-panel and after-panel responses to questions Q1 (meeting spouse/partner), Q2 (two jobs in same location), Q3 (parental leave), and Q4 (time to spend with children). Clear bars: men or women who changed to thinking balance would be more difficult in STEM after the panel discussions. Solid: all men or all women who responded to the question in the survey.

The college years are not too early to address work-life balance in the context of career decision making. Because the traditional college student is unmarried and does not have children, it is easy to overlook the part that students' perceptions of work-life balance might have on their career decisions. With a few exceptions, such as a website featuring
Table 3. Students' comments regarding the work-life balance panel discussions

\begin{tabular}{|c|c|c|c|c|}
\hline \multirow{2}{*}{$\begin{array}{l}\text { Themes of comments } \\
\text { Not receptive to the topic }\end{array}$} & \multicolumn{2}{|c|}{ Men } & \multicolumn{2}{|c|}{ Women } \\
\hline & 1 & $2 \%$ & 0 & $0 \%$ \\
\hline $\begin{array}{l}\text { Information was insightful, } \\
\text { good to have, will help future } \\
\text { decision. }\end{array}$ & 12 & $27 \%$ & 8 & $23 \%$ \\
\hline Information was enabling. & 32 & $69 \%$ & 27 & $77 \%$ \\
\hline \multicolumn{5}{|l|}{ Comments: } \\
\hline Is doable, is possible & 12 & $27 \%$ & 9 & $26 \%$ \\
\hline $\begin{array}{l}\text { Is not as hard as I thought it } \\
\text { would be, takes planning }\end{array}$ & 4 & $9 \%$ & 3 & $8 \%$ \\
\hline $\begin{array}{l}\text { Is possible but hard, will take } \\
\text { effort on my part }\end{array}$ & 3 & $7 \%$ & 10 & $29 \%$ \\
\hline Is possible with the right partner & 5 & $11 \%$ & 3 & $8 \%$ \\
\hline $\begin{array}{l}\text { Employers are part of the } \\
\text { solution. }\end{array}$ & 2 & $4 \%$ & 0 & $0 \%$ \\
\hline Flexibility is important. & 5 & $11 \%$ & 2 & $6 \%$ \\
\hline
\end{tabular}

interviews of mostly female faculty members discussing their family lives and careers (STEM Career-Life Balance Resource Center, 2014), the issue of work-life balance relative to STEM is usually addressed only for those already in the workforce (Preston, 2004; Council of Economic Advisers, 2010; Fouad et al., 2012) or pursuing graduate studies (Mason et al., 2009). The results of our survey before the panel discussions show the need to address work-life balance during the undergraduate years. It is important that STEM majors do not make crucial decisions on what studies or work to pursue upon graduation while harboring the preconception that a research-based STEM career is incompatible with the family life they desire. Moreover, it is best if the students receive information about work-life balance in structured settings in which they are exposed to role models who are living the lives and doing the work that the students envision themselves doing in the future. Otherwise, students will shape their expectations based on their occasional isolated observations of the lifestyles of faculty mentors and other research scientists they happen to know (Gibbs and Griffin, 2013).

With our group of students, we have demonstrated the effectiveness of our simple intervention, a panel discussion in which STEM research professionals and partners in dual-career families discuss work and balancing work with raising children. Our desired outcome was that the students would realize that work-life balance would be no easier or harder to attain in research-based STEM careers versus alternative professions. We attained this outcome for the majority of the students, both men and women, with the impact of the intervention being greater on the women, especially on the issues they were most anxious about, those relating to parental leaves and having time to spend with children. We believed it was important to have both male and female STEM professionals on the panels to provide role models for both male and female students and also to allow the students to view work-life balance from the perspective of the opposite gender. We could have invited male and female individuals to talk about their families and careers; however, we think that seeing and listening to 
partners as they took turns filling in details of how they met the major challenges to balancing work and family delivered a powerful message. At times, the panels worked out even better than planned. Although we arranged for babysitting, a toddler preferring to stay by his parents spent the evening quietly making marks on the chalkboard that he could barely reach, going to each of his parents once in a while for a hug. We could not have planned a better image of scientists and engineers who succeed in enjoying both work and family.

Besides having gained information that would help them make better-informed career decisions, students showed in their comments that they also gained self-confidence in their ability to have a family while advancing in a profession of their choice, including one that they could attain should they choose graduate studies in a STEM discipline. The pre- and postpanel survey was a key aspect of our intervention that, we believe, contributed to its success. Recommendations for improving undergraduate STEM mentoring stress the need for timely reflection by the mentee (Linn et al., 2015). Posing the questions to the undergraduates immediately before the panel sessions gave the students an opportunity to identify their feelings about their desired work-life balance and so set the stage for them to be even more engaged in what the panelists had to say. In turn, the postpanel survey provided an opportunity for the undergraduates to think over what they had heard and reconsider their perspectives on these issues.

That we achieved our desired outcome with different sets of panelists suggests that this intervention can work elsewhere. It is quite common for institutions, STEM faculty, and granting agencies to fund undergraduate research to encourage students to pursue graduate studies in STEM. A panel discussion of dual-career couples in the STEM professions discussing how they achieve work-life balance is a low-cost intervention that will help to increase return on this investment. Our intervention may also be applied to other groups of STEM undergraduate students, especially early in their college years. In addition, considering reports of graduate students and postdoctoral fellows who think of leaving STEM based on work-life balance concerns (Mason et al., 2009; Wyss and Tai, 2010; Gibbs and Griffin, 2013), this intervention may help stem the loss from their ranks. Before implementation, we suggest some informal polling or discussion with students to determine the aspects of work-life balance of concern to them in order to define key issues for the panelists to focus on.

\section{ACKNOWLEDGMENTS}

This work was supported in part by grants to Binghamton University from the Howard Hughes Medical Institute through the Precollege and Undergraduate Science Education Program and from the SUNY Research Foundation to conduct a research training program for undergraduate STEM majors. We thank all the panelists for sharing their stories with the students. We thank Sura Alqudah and Fatima Irshaidat for alerting us to students' concerns about work-life balance, Mandana Rezaeiahari for assistance with initial analyses, Dr. Mohammad Khasawneh for directing their work, and Elizabeth Button for input into planning of the panel discussions. We have Binghamton University's IRB approval (\#1302-09) for the work described in this article.

\section{REFERENCES}

Adema W (2013). Greater gender equality: what role for family policy? Fam Matters 93, 7-16.

Betz NE (2004). Contributions of self-efficacy theory to career counseling: a personal perspective. Career Dev Q 52, 340-353.

Carlson DS, Kacmar KM, Wayne JH, Grzywacz JG (2006). Measuring the positive side of the work-family interface: development and validation of a work-family enrichment scale. J Vocat Behav 68, 131-164.

Carlson DS, Kacmar KM, Williams LJ (2000). Construction and initial validation of a multidimensional measure of work-family conflict. J Vocat Behav 56, 249-276.

Chait Barnett R, Gareis KC, Boone James J, Steele J (2003). Planning ahead: college seniors' concerns about career-marriage conflict. J Vocat Behav 62, 305-319.

Change the Equation (2011). STEM Help Wanted: Demand for Science, Technology, Engineering and Mathematics Weathers the Storm, Washington, DC. http:/ / changetheequation.org/sites/default/files/ CTEq_VitalSigns_Supply\%20\%282\%29.pdf (accessed 9 March 2015).

Chen X, Soldner M (2013). STEM Attrition: College Students' Paths Into and Out of STEM Fields, NCES 2014-001, Washington, DC: National Center for Education Statistics, U.S. Department of Education. http:/ / nces.ed.gov/pubs2014/2014001rev.pdf (accessed 9 October 2014).

Cinamon RG (2006). Anticipated work-family conflict: effects of gender, self-efficacy, and family background. Career Dev Q 54, 202-215.

Cinamon RG, Rich Y, Westman M (2007). Teachers' occupation-specific work-family conflict. Career Dev Q 55, 249-261.

Columbia University Center for Career Education (2015). Career Exploration for Ph.D.s in Science, Technology, Engineering, and Math Disciplines. www.careereducation.columbia.edu/print/1014 (accessed 25 March 2015).

Committee on Science Engineering and Public Policy (2010). Rising above the Gathering Storm, Revisited: Rapidly Approaching Category 5, Washington, DC: National Academies Press.

Council of Economic Advisers (2010). Work-Life Balance and the Economics of Workplace Flexibility, Washington, DC: Executive Office of the President of the United States. www.whitehouse.gov/ files / documents / 100331-cea-economics-workplace-flexibility.pdf (accessed 23 October 2015).

D'Ecclessis M (2013). 11 Alternative Careers for Ph.D. Students. http:/ / www.nextscientist.com/alternative-careers-for-phd-students/ (accessed 25 March 2015).

Demerouti E, Peeters MCW, van der Heijden BIJM (2012). Workfamily interface from a life and career stage perspective: the role of demands and resources. Int J Psychol 47, 241-258.

Ecklund EH, Lincoln AE (2011). Scientists want more children. PLoS One 6, e22590.

Elliott VS (2011). Residents' desire for hospital employment poses recruiting challenge for practices. American Medical News, October 24. www.amednews.com/article/20111024/business/310249968/1 (accessed 6 September 2014).

Fouad NA, Singh R, Fitzpatrick ME, Liu IP (2012). Stemming the Tide: Why Women Leave Engineering. http://studyofwork.com/ files/2011/03/NSF_Women-Full-Report-0314.pdf (accessed 29 October 2014).

Friedman SR, Weissbrod CS (2005). Work and family commitment and decision-making status among emerging adults. Sex Roles 53, 317-325.

Fry R (2015). This Year, Millennials Will Overtake Baby Boomers, Washington, DC: Pew Research Center. www.pewresearch .org/fact-tank/2015/01/16/this-year-millennials-will-overtake -baby-boomers/ (accessed 24 June 2015). 
Fuhrmann CN, Halme DG, O'Sullivan PS, Lindstaedt B (2011). Improving graduate education to support a branching career pipeline: recommendations based on a survey of doctoral students in the basic biomedical sciences. CBE Life Sci Educ 10, 239-249.

Gibbs KD Jr, Griffin KA (2013). What do I want to be with my PhD? The roles of personal values and structural dynamics in shaping the career interests of recent biomedical science $\mathrm{PhD}$ graduates. CBE Life Sci Educ 12, 711-723.

Gibson DE (2003). Developing the professional self-concept: role model construals in early, middle, and late career stages. Organ Sci 14, 591-610.

Glass JL, Sassler S, Levitte Y, Michelmore KM (2013). What's so special about STEM? A comparison of women's retention in STEM and professional occupations. Soc Forces 92, 723-756.

Goulden M, Frasch K, Mason MA (2009). Staying Competitive: Patching America's Leaky Pipeline in the Sciences, Washington, DC: Center for American Progress. https://cdn.americanprogress.org/ wp-content/uploads/issues/2009/11/pdf/women_and_sciences .pdf (accessed 5 March 2015).

Graham MJ, Frederick J, Byars-Winston A, Hunter AB, Handelsman $\mathrm{J}$ (2013). Science education. Increasing persistence of college students in STEM. Science 341, 1455-1456.

Grawitch MJ, Barber LK, Justice L (2010). Rethinking the work-life interface: it's not about balance, it's about resource allocation. Appl Psychol Health Well-Being 2, 127-159.

Greenhaus JH, Allen TD (2011). Work-family balance: a review and extension of the literature. In: Handbook of Occupational Health Psychology, ed. JC Quick and LE Tetrick, Washington DC: American Psychological Association, 165-183.

Kalliath T, Brough P (2008). Work-life balance: a review of the meaning of the balance construct. J Manage Organ 14, 323-327.

Landivar LC (2013a). The Relationship between Science and Engineering Education and Employment in STEM Occupations, American Community Survey Reports ACS-23, Washington, DC: U.S. Census Bureau. www.census.gov/prod/2013pubs/acs-23.pdf (accessed 6 September 2014).

Landivar LC (2013b). Disparities in STEM Employment by Sex, Race, and Hispanic Origin, American Community Survey Reports ACS-24, Washington, DC: U.S. Census Bureau. www.census.gov/ prod/2013pubs/acs-24.pdf (accessed 6 October 2014).

Linn MC, Palmer E, Baranger A, Gerard E, Stone E (2015). Undergraduate research experiences: impacts and opportunities. Science 347, 1261757-1261761.

Loughlin C, Barling J (2001). Young workers' work values, attitudes, and behaviours. J Occup Organ Psychol 74, 543-558.

Mason MA, Goulden M, Frasch K (2009). Why graduate students reject the fast track. Academe 95, 11-16.

Miranda V (2011). Cooking, Caring and Volunteering: Unpaid Work Around the World, OECD Social, Employment and Migration Working Papers no. 116. www.keepeek.com/Digital-Asset-Management/ oecd/social-issues-migration-health / cooking-caring-and -volunteering-unpaid-work-around-the-world_5kghrjm8s142 -en\#page1 (accessed 4 March 2015).

National Academy of Sciences, National Academy of Engineering, Institute of Medicine (2011). Expanding Underrepresented Minority Participation: America's Science and Technology Talent at the Crossroads, Washington, DC: National Academies Press.
National Center for Education Statistics (2011). Postsecondary Awards in Science, Technology, Engineering, and Mathematics by State: 2001 and 2009, Washington, DC: U.S. Department of Education. http:// nces.ed.gov/pubs2011/2011226.pdf (accessed 8 October 2014).

National Center for Education Statistics (2013). Digest of Education Statistics, NCES 2014-015, Washington, DC: U.S. Department of Education.

National Chamber Foundation (2012). The millennial generation. Research review. www.uschamberfoundation.org/sites/default/ files/article/foundation/MillennialGeneration.pdf (accessed 7 October 2014).

National Girls Collaborative Project (2013). The State of Girls and Women in STEM, Lynnwood, WA: National Girls Collaborative Project. www.ngcproject.org/sites/default/files/documents/ ngcpstemstats_web.pdf (accessed 4 October 2014).

National Science Board (2014). Science and Engineering Indicators 2014, NSB 14-01, Arlington, VA: National Science Foundation.

Parker K, Wang W (2013). Modern Parenthood. Roles of Moms and Dads Converge as They Balance Work and Family. Washington, DC: PEW Research Center. www.pewsocialtrends.org/2013/03/14/ modern-parenthood-roles-of-moms-and-dads-converge-as-they -balance-work-and-family (accessed 1 March 2015).

Preston AE (2004). Plugging the leaks in the scientific workforce. Issues Sci Technol. http://issues.org/20-4/preston (accessed 9 March 2015).

Resneck JS Jr (2006). The influence of controllable lifestyle on medical student specialty choice. Virtual Mentor 8, 529-532.

Rothbard NP (2001). Enriching or depleting? The dynamics of engagement in work and family roles. Admin Sci Q 46, 655-684.

Science and Technology Committee (2014). Women in Scientific Careers, London, UK: U.K. House of Commons. www.publications .parliament.uk/pa/cm201314/cmselect/cmsctech/701/70102.htm (accessed 21 October 2014).

Shelton M (2013). A day in the life of a financial analyst. Investopedia, January 21. www.investopedia.com/financial-edge/0213/aday-in-the-life-of-a-financial-analyst.aspx (accessed 9 October 2014).

STEM Career-Life Balance Resource Center (2014). Home page. http:/ /ugr.ue.ucsc.edu/CLB (accessed 9 October 2014).

Tausig M, Fenwick R (2001). Unbinding time: alternate work schedules and work-life balance. J Family Econ Issues 22, 101-119.

Tucson Values Teachers (2013). The State of the Teacher: Teacher Work Force Study. http:/ / tucsonvaluesteachers.org/pdf/TVT-2013 -teacher-survey-summary.pdf (accessed 17 October 2014).

Turk-Bicakci L, Berger A, Haxton C (2014). The Non-Academic Careers of STEM Ph.D. Holders, Washington DC: American Institutes for Research. www.air.org/sites/default/files/downloads/report/ STEM\%20nonacademic\%20careers\%20April14.pdf (accessed 14 October 2014).

Twenge JM, Campbell SM, Hoffman BJ, Lance CE (2010). Generational differences in work values: leisure and extrinsic values increasing, social and intrinsic values decreasing. J Manage 36, 1117-1142.

U.S. Census Bureau (2014). Where Do College Graduates Work? A Special Focus on Science, Technology, Engineering and Mathematics. www.census.gov/dataviz/visualizations/stem/stem-html (accessed 25 March 2015).

Williams W, Ceci SJ (2012). When scientists choose motherhood. Am Sci 100, 138-145.

Wyss VL, Tai RH (2010). Conflicts between graduate study in science and family life. Coll Stud J 44, 475-491. 